\title{
Contract and Tort after Denning
}

\author{
M. P. Furmston*
}

My brief is to discuss the ways in which English Contract and Tort law might develop in the rest of the century. ${ }^{1}$ The time is propitious for such a review since of the four great figures who have done so much to shape the development of Contract and Tort law since the war - Lord Denning, Lord Diplock, Lord Reid and Lord Wilberforce, ${ }^{2}$ three have recently departed from the courts, Lord Denning and Wilberforce by retirement and Lord Diplock, alas, by death. This permits, and perhaps requires, a pause for reflection and regrouping.

If an attempt to answer the question is rash, the posing of the question itself makes some assumptions which are not self evident. To foretell the future assumes that progress will have at least a significant rational element. One of our greatest living historians, A. J. P. Taylor, has often argued that on the whole things happen by accident and are not the product of determinist trends. It is difficult not to feel that there is at least a significant accidental element in the development of common law through the process of deciding cases. In a sense the law is at the mercy of litigants since if no litigant brings a question before the courts and in particular if no appellant brings it before the House of Lords, developments which are possible may be held up for generations. For instance it seems probable that if some suitable case with appropriate facts had come before the House of Lords in the seventies, they would have taken the opportunity to abolish or at least seriously to qualify the doctrine of privity of contract. Even when cases do come before the Lords, much may turn on accidents of timing. So it is plausible to speculate that if the La Pintada ${ }^{3}$ case had come before the House of Lords before the Law Commission had recommended the abolition of the general rule that interest was not payable on debts in the absence of agreement, ${ }^{4}$ their Lordships might have

\section{* Professor of Law, University of Bristol.}

1. A revised version of a paper given at a symposium on Anglo-Japanese Law at the University of Warwick on 19 December 1986. I am grateful to Hugh Beale and Keith Stanton for comments on an earlier draft.

2. The order is alphabetical.

3. [1985] A.C.104.

4. Law Commission No 88, Cmnd. 7229. 
taken the opportunity to overturn this long-entrenched but barely justifiable rule. Even where a problem occurs so frequently that it is almost inevitable that sooner or later it will come before the courts, much may turn on the way in which the merits appear in the particular case, on the forensic tactics used by counsel and indeed, on the composition of the House of Lords itself. It is not absurd to suggest that if Donoghue v. Stevenson ${ }^{5}$ had been decided by a majority of 3:2 in the opposite direction, English law would look rather different today than it does. Professor Schwartz has recently explained the decision of the plaintiff in the important Californian case of f'aire $^{6}$ to pursue an apparently speculative claim in tort rather than a clear cut claim in contract against a different defendant on the basis of the confession of the plaintiff's attorney that "contracts was never my subject in law school"?

Despite all these qualifications many common lawyers looking back into the past will find lines of development which seem, at least in retrospect, logically coherent if not inevitable. Is it entirely a coincidence that the American courts in $M c$ Pherson v. Buick $^{8}$ reached substantially the same result as the English courts in Donoghue v. Stevenson? ? May there not be something in the logic of the system or the needs of the times which produces similar results in similar places. One of the revelations of comparative law, indeed, is how often the logic of different systems seems to lead to the same result, presumably because of the need to respond to similar social problems. When we turn from case law to legislation, though it is true that most academic lawyers despair from time to time of the possibility of Parliament pursuing rational policies in law reform, it is true that in retrospect one can identify developments such as the introduction of Criminal Appeals or the right of the accused to testify at his own criminal trial, which seem inevitable even though at the time they were highly contentious and violently resisted.

To continue at this point therefore, indicates a belief that one can have at least a stab at identifying the future by looking at what has taken place over the last twenty-five years and trying to identify in what directions development scems to follow from this.

Prediction of future trends assumes the ability to identify the relevant forces for change. Without being clearly able to ascribe a precise weight to different forces I start by assuming in what follows that change is partly fuelled by the perceived inherent logic of the system amongst its practitioners; partly by a response to the perceived needs of society as revealed by the accidents of litigation and partly by the choice of subjects for legislative law reform. In this respect a factor that seems to me so far to have been underestimated is the switch to a wholly graduate entry

5. [1932] A.C.562.

6. 24 Cal. 3d 799, 598 P. 2d 60, 157 Cal. Rptr 407 (1979).

7. In The Law of Tort: Policies and Trends in Liability for Damage to Property and Economic Loss ed. Furmston (Duckworth, 1986), at p.86.

8. 217 NY 382, 111 NE 1050 (1916).

9. [1932] A.C.562. 
into the profession which will mean within a generation a wholly graduate profession. These graduates will be overwhelmingly law graduates and even those who are not law graduates will have received at least two years of systematic instruction in the law. I find it difficult to believe that this will not have a substantial effect on the way in which future generations of lawyers will analyse legal problems. Most of us, if we are honest, will admit that many of our ideas were fixed at an early age by the conceptual structure of the subjects as they were taught to us. If this is true then internal developments within university law schools in the way in which the subject is taught will in their turn have effects on how practitioners perceive problems.

\section{The relationship of contract and tort}

One of the most interesting questions which the courts will have to work out over the next twenty years is the relationship between Contract and Tort. This has a number of aspects. One is attempts by a plaintiff to allege that he has a claim in tort even though he has a claim in contract against the same defendant arising out of the same facts. This problem has in practice arisen primarily in the context of limitation. In this context the fact that the limitation period in contract starts when the contract is broken but that in tort starts when the plaintiff suffers damage means that there may be significant advantages in suing in tort rather than contract for this purpose. After an initial rejection of this possibility by Diplock L. J. sitting as a High Court judge in Bagot v. Stevens, Scanlan, ${ }^{10}$ it was accepted in a very full and carefully reasoned judgment by Oliver J. in Midland Bank v. Hett Stubbs and Kemp. ${ }^{11}$ This decision was expressly approved by the Court of Appeal in Batty v. Metropolitan Realisations Limited ${ }^{12}$ and in the leading House of Lords decision of Pirelli v. Faber, ${ }^{13}$ the defendant did not even think it worth while to argue that the plaintiff, who undoubtedly had a good but statute barred claim in contract could not pursue a claim in tort on the same facts.

The only discordant note in this picture is the opinion of the Privy Council in Tai Hing Cotton Mill Limited v. Liu Chong Hing Bank Limited. ${ }^{14}$ In this case Lord Scarman said, "Their Lordships do not believe that there is anything to the advantage of the law's development in searching for a liability in tort where the parties are in a contractual relationship." On one view this might be taken as disapproval of the reasoning in Midland Bank but it seems in fact unlikely that this is so. Certainly courts in cases after Tai Hing have continued to treat the Midland Bank approach as entirely correct in the limitation context. ${ }^{15}$ In interpreting Tai Hing it is important to note that the Privy Council was first of all invited to extend

10. [1966] 1 Q.B.197.

11. [1979] Ch.384.

12. [1978] Q.B.554.

13. [1983] 2 A.C.1; see Furmston, 1 Consinuction L.R.25.

14. [1985] 2 All E.R.947.

15. See, e.g., London Congregational Union v. Harriss (1986) 8 Construction L.R.52 
the implied obligations of the customer to his bank in contract; then when that approach was rejected, to outflank its own decision by holding the customer as under a duty of care in tort. It seems entirely rational to say that the underlying policy considerations were identical whether the question was posed as a contract or a tort question and should therefore receive the same answer. ${ }^{16}$ It would be strikingly inconvenient if the Tai Hing opinion were applied in the limitation context since it seems clear that the Latent Damage Act 1986 assumes the correctness of Midland Bank. One of the paradoxes of this area was that Lord Scarman sat in Pirelliv. Faber and was one of the principal architects of the Latent Damage Act 1986.

Another development has been an attempt by plaintiffs to invoke the law of tort in order to outflank the problems presented by the law of contract, particularly the doctrine of privity of contract. These attempts mirror in a way attempts by previous generations in cases such as De La Bere v. Pearson ${ }^{17}$ to overcome defects in the law of tort (particularly the absence of liability for careless statements) by stretching the law of contract. Some of these developments are discussed below in relation to economic loss.

Some scholars have deduced from these developments that the law of contract and tort are coalescing. ${ }^{18}$ Some, indeed, have spoken of the emergence of "contort" or the death of contract. Undoubtedly, it is now important for contract and tort lawyers to be aware of developments in each others' subjects, but for the moment developments seem rather to emphasise the distinction between contract and tort than to mark their confluence. If the law in tort and contract were indeed flowing in a single channel, the results of cases would have surely been the same, whether they were formulated in contract or tort. To permit a plaintiff who has failed in contract to succeed in tort on identical facts against the same defendant, or vice versa, seems rather to point up the distinctiveness of the rules than to reflect their assimilation.

Of course there must be serious doubts when different results are produced on the same facts, according to which of two apparently equally valid analyses are adopted. This result, however, seems inevitable, unless one is to go down the French road and adopt the rule of non-cumul. ${ }^{19}$ If we take the case of defective

16. The present writer must confess to grave doubts as to whether the Privy Council ought not to have accepted the invitation to develop the law in this area by widening liability in contract. The effective question in the case was, who should bear the risk of the plaintiff's dishonest servant. Since even the most elementary precautions by the plaintiffs would have revealed his dishonesty at an early stage, it seems hard to apportion all the loss onto the bank since it is much more difficult to see what practical steps the bank could have taken to reduce the chances of loss. It is of course entirely understandable that the Privy Council should not wish to have gone to the other extreme and held that all customers were under obligation to check their statements. One wonders, however, whether it were not possible to develop some distinction between commercial and private customers in this area.

17. [1908] I K.B.280.

18. See particularly Cane in The Law of Tort, supra n.7, ch.6.

19. See Herbots in The Law of Tort, supra n.7, ch.7 at p.139. 
buildings, it is clear that some plaintiffs will only have actions in torts; for instance, because they did not contract with the person who is at fault. In the case of such plaintiffs, limitation periods would inevitably start when damage is suffered. Some other plaintiffs will have a choice of suing in contract or tort but it would be difficult to justify their tort claims being rejected simply because their contract claims had been rejected when they had neighbours who were in a different position. That might mean that the second hand buyer could sue the developer when the first purchaser could not.

\section{Tort}

Collapse of the personal injury system?

I cannot myself believe that our existing system for personal injury will continue unreformed into the indefinite future. The criticisms of the existing system have been too often and too well rehearsed to justify repetition here. ${ }^{20}$ Suffice it to say that the existing system consumes an unacceptably large amount of resources in its operation and that in practice it spreads the compensation monies across those injured in a way which is totally erratic, irrational and unjustifiable. Sometimes when I make this statement I am told by the audience that vested interests in the present system are too strong for it not to survive. I am reluctant to believe this and contrariwise encouraged by signs that the medical profession is beginning to see the attractions of a system that does not require repeated enquiries into the carelessness of doctors. ${ }^{21}$ A struggle between the vested interests of doctors on the one hand and personal injury lawyers and insurance companies on the other would be interesting to watch. I think I know which horse I would back.

\section{Growth of professional negligence litigation}

The last twenty years have seen a major growth in the willingness of plaintiffs to sue their professional advisors. If one is concerned with a plaintiff who brings a contract action against his own advisor, there has been very little formal change in the law here but a marked increase in willingness to sue. If one considers claims formulated in tort, whether against one's own advisor or against other people's advisors, there has been an explosion of liability since Hedley Byme including such decisions as Ross v. Caunters which would have appeared unthinkable thirty years ago. If we make the plausible assumption that in this field English courts will go some way down the American road, this suggests further geometric increase in professional liability actions. Stories, obviously inspired, now regularly appear in the papers about the burdens of insuring against professional negligence and professional bodies, indeed, have grouped together to seek to persuade the government to impose statutory limits on negligence liability. The attraction of this is said to be that it would make insurance problems significantly easier to

20. See, for instance, Atiyah, Accidents, Compensation and the Law.

21. See, e.g., Stirrat, [1986] 101 Bristol Medico-Chinurgical Joumal. 
overcome. It seems likely however, that the government will resist these blandishments. In any case, it is hardly likely that public opinion would tolerate any limit which was not so large as to leave only a very small number of claims over the limit. It is rumoured that some large firms of accountants have been sued for sums well into nine figures. It seems very doubtful whether judgments of this size could be effectively enforced against the partners of a firm, however large, if it was well in excess of their insurance limit. In any case, if a careless accountant actually causes loss of this scale it is not self-evident that he should not bear it so far as he is able or insured, unless it can be shown that it would be much cheaper and more efficient for the victim to insure. $A$ priori this seems doubtful.

It is no doubt a legitimate question whether tort actions for professional negligence are in fact the appropriate way to improve levels of professional competence. There are however, serious grounds for doubt as to how widespread competence is. The professions have only recently begun to bestir themselves in this respect. In particular, granted the complexity and rapid evolution of modern professional skills, the relatively modest programmes of post-qualification continuing education so far adopted are very much a first step. If the professions seek special treatment the least the public should demand in return is that the professions themselves should demonstrate heroic efforts to raise standards.

\section{The development of the tort of negligence}

If one had been asked to present this paper in 1982, the discussion of this section would have appeared much easier. Up until that period the post-war developments appeared to reflect a consistent trend towards a hegemony of the tort of negligence within tort law. By this I mean two rather separate developments - the one is a movement away from strict liability, at least in respect of the central area of damage to person and property. So successful actions under the rule in Rylands $\mathrm{v}$. Fletcher are nowadays virtually unknown and the tort of nuisance has been afflicted, admittedly to a degree difficult to define precisely, by ideas of negligence. ${ }^{22}$

In 1982, one would have been inclined to discount as an immediate possibility the one major departure from this trend which is now evident, that is, the introduction by statute of a strict liability regime for products. Although I welcome this development as an improvement on the present law, it is not easy to think of a principled reason for introducing this regime for products only and continuing to operate a negligence regime for road accidents. Only the almost fortuitous fact that it is possible to think of plausible EEC constitutional reasons for a uniform regime for products but so far impossible to think of similar reasons for a uniform regime for car accidents produces this change. In any case, the existing reform is probably not a very great step forward since the permission of the development risk defence will introduce some questions of fault and in any case the need to operate through the legal system and the possibility of raising defences based on causation or

22. See particularly The Wagon Mound (No 2) [1967] 1 A.C.617. 
contributory negligence will mean that the plaintiff will often fall short of full recovery. To this writer at least, strict liability appears a second best alternative to a socially funded scheme. The development does underline however the importance of membership of the EEC as a reason for legislative initiatives.

When I talk of the hegemony of negligence I have also, perhaps more importantly, in mind the apparently inevitable assumption that a defendant who has been negligent should always be liable. So during the sixties, seventies and early eighties, a number of apparently well established exceptions to this principle crumbled away. The special treatment of buildings appeared to collapse in the face of Dutton v. Bognor Regis ${ }^{23}$ and Anns v. Merton; ${ }^{24}$ the special treatment of nervous shock was made much less special by McLoughlin v. $O^{\prime} B r i a n ;{ }^{25}$ the special immunity of careless statements was removed by Hedley Byme ${ }^{26}$ and its successors, and an apparently major inroad into immunity for the negligent causing of pure economic loss was made by the decision in funior Books v. Veitchi. ${ }^{27}$ In 1982, immediately after funior Books v. Veitchi, it was plausible to assume that English law would find it very difficult to find a stopping place short of complete surrender to the principle that careless defendants would always be liable. ${ }^{28}$ This was puzzling since the forces which fuelled this development seemed to be entirely conceptual. The notion that he who is careless must pay seemed to be an idea whose time had come. In this respect I cannot help thinking that it was significant that in a very large number of leading negligence cases the court was deciding, without knowing what the facts were, because for procedural reasons the defendant had chosen to fight on the basis that although he was careless he owed no duty of care to the defendant. So for instance, in Donoghue v. Stevenson, ${ }^{29}$ Hedley Byme v. Heller, ${ }^{30}$ Dorset Yacht v. Home Office, ${ }^{31}$ Rondel v. Worsley, ${ }^{32}$ Anns v. Merton ${ }^{33}$ and funior Books v. Veitchi, ${ }^{34}$ the court was in effect invited to take the defendant's carelessness as read. In several of these cases the defendant had possible arguments that he was not careless but these were not considered by the court. Is it not plausible to suggest that that circumstance deprived the court of that perception of the real balance of advantages and balancing of risks which would have emerged from a careful evaluation of the facts as a preliminary to the development of the law?

23. [1972] 1 Q.B.373.

24. [1978] A.C.728.

25. [1983] 1 A.C.410.

26. [1964] A.C. 465 .

27. [1983] 1 A.C.520.

28. For a fuller discussion of the position as it seemed after funior Books see Stanton in The Law of

Tort, supra n.7, ch.1.

29. [1932] A.C.562.

30. [1964[ A.C. 465 .

31. [1970] A.C.1004.

32. [1969] 1 A.C.191.

33. [1978] A.C.728.

34. [1983] 1 A.C.520. 
Whatever the merits of this argument, it seems clear that the period 1982 to 1986 has been marked by a complete stop in this development, if not indeed by a U-turn. So such cases as The Aliakmon ${ }^{35}$ Peabody v. Parkinson, ${ }^{36}$ Candlemood v. Mitsui $^{37}$ and Muirhead v. Industrial Tank ${ }^{38}$ indicate that the courts are certainly not prepared to carry the decision in funior Books one step further and indeed indicate that given the right facts they might be prepared to push it a few steps backwards. At the same time courts have been rebuffing attempts to introduce stricter forms of liability in personal injury cases whether based on suing in battery (Chatterton $\mathrm{v}$. Gerson), ${ }^{39}$ on allegations of warranty (Thake v. Maurice) ${ }^{40}$ or use of "informed consent" (Sidamay v. Bethlem Royal Hospital Governors). ${ }^{41}$

Although some and perhaps all of these cases can be defended on the merits ${ }^{42}$ their cumulative effect is to present a conservative and indeed rather negative posture. At a theoretical level the most important ingredient in the cases is the attempt to resile from the two stage approach of Lord Wilberforce. In some cases this appears to involve an abandonment or at least a downgrading of arguments based on policy. As far as the law of economic loss is concerned, we seem to have moved from a position in which one might say that sometimes one can recover for it and sometimes not, to a position in which one can say sometimes one cannot recover for it and sometimes one can! Neither the expansion of liability in funior Books nor its contraction in the later cases can be said to present a coherent principled exposition of where the line is to be drawn between that economic loss which is recoverable and that which is not. It is clear that some cases of recoverable economic loss still exist, particularly in relation to careless statements (and there has been no suggestion that Ross v. Caunters ${ }^{43}$ is wrongly decided). One who looks to the future has to guess whether recent developments are simply a halting point in the march forward or whether there is indeed a reversal. In this respect one may perhaps draw attention to another factor in the development of the common law by judicial decision which I call the revulsion factor. After each of the most important steps forward such as Donoghue v. Stevenson ${ }^{44}$ and Hedley Byrme v. Heller, ${ }^{45}$ we tend to have a period of five or ten years in which judges cannot actually believe the evidence of their eyes. So cases decided in the thirties and forties often indicated a

35. [1986] 2 All E.R.145.

36. [1985] A.C.210.

37. [1986] A.C.1.

38. [1985] 3 All E.R.705.

39. [1981] Q.B.432.

40. [1986] 1 All E.R.497.

41. [1985] A.C.871.

42. Though not all the commentators have thought so. See, e.g., Clarke, [1986] C.L.7.382; Markesinis, [1986] C.L.7.384. Parliament it seems, may have reversed The Aliakmon in a fit of absence of mind by Section 3(1) of Latent Damage Act 1986 - see Griew, 136 New Law Joumal 1201.

43. [1980] Ch.297.

44. [1932] A.C.562.

45. [1964] A.C.465. 
reluctance to take Donoghue v. Stevenson as laying down general principles of the kind which we now take for granted.

Similarly, the immediate post-Hedley Byrne cases, particularly Mutual Life v. Evatt ${ }^{46}$ but also a number of decisions at first instance, indicated a reluctance to believe that the House of Lords had actually made the change it had. Yet in both these cases, after a time, the broader view of the effect of the cases became established within the collective wisdom of the profession which is in practice such an important though intangible source of law making. It is not inconceivable that the same process will happen with funior Books v. Veitchi though it would perhaps be a rash lawyer who would confidently predict that it would.

\section{Contracts}

It is possible to view the development of the law of contract as reflecting the different weight given at different times to the values of freedom of contract and of paternalism. Certainly many developments in the law of contract over the last twenty-five years can be discussed in these terms. ${ }^{47}$ For this purpose I am inclined to put forward a thesis that this battle will never be won by one side or the other, and that the real question is not whether paternalism should prevail over freedom of contract or vice versa but where exactly the borderline between their respective spheres of influence should lie.

\section{Exemption clauses}

One of the major battle areas in recent years has been the treatment of exemption clauses. The substantive doctrine of fundamental breach as propounded by Lord Denning in many cases in the Court of Appeal, represented an entirely understandable attempt to ensure fair dealing for such consumers as purchasers of shoddy second hand cars. It proved impossible however to develop a doctrine which both worked and had real intellectual coherence. As Professor Brian Coote has all too clearly exposed, a system which ignores the distinction between clauses defining liability and clauses seeking to exclude a liability already accepted, will run into endless difficulties. ${ }^{48}$ Furthermore at the pragmatic level the substantive doctrine of fundamental breach ran into fatal difficulties when it attempted to expand from the area of consumer protection into straightforward commercial contracts as in Harbutts Plasticine $e^{49}$ and Photo Production v. Securicor ${ }^{50}$ In this respect the Unfair Contract Terms Act of 1977 has undoubtedly permitted the courts to move back to a more reasoned approach, ${ }^{51}$ confident that most of the

46. [1971] A.C.793.

47. See Collins, The Law of Contract (1986) and the reviews by Reynolds, 102 L.Q.R.628 and Weir, [1986] C.L.7.503 for different views.

48. Exception Clauses (1964).

49. [1970] 1 Q.B.447.

50. [1980] A.C.827.

51. Photo Production v. Securicor [1980] A.C.827; Ailsa Craig Fishing v. Malvern Fishing [1983] 1 W.L.R.964. 
practical problems which have actually given rise to litigation in the past have been taken care of, even though the Act exempts some transactions from its scope (such as sales of land, and policies of insurance) where the case for so-doing is far from clearly demonstrated.

One of the most controversial decisions implicit in the 1977 Act was the granting of power to the courts to declare many exemption clauses in commercial contracts void because unreasonable. Since businessmen are certainly entitled to make foolish contracts in general, it is not wholly clear why they should be prohibited from entering into foolish exemption terms. Furthermore it can be plausibly argued that it is very difficult for a court to come to a decision on whether a clause is or is not reasonable without an examination of the whole business background and context which is unlikely to be possible in the forum of litigation where the cost is likely to deter all but the most determined parties from presenting the relevant business information to the court. It is striking in this respect that the majority of decisions on reasonableness so far have tended to reach the conclusion that the particular clause litigated was unreasonable. One important message to contracting parties, is that they should employ lawyers who can devise clauses which look reasonable rather than relying, as lawyers rather evasively have in the past, on attempts to exclude liability for everything. In a rational world this ought to lead to more contracts where liability is limited rather than excluded and where the insurance burden is clearly determined by the contract. Indeed, it is noticeable that in some of the most complex contracts such as major building contracts, the very sensible practice of all the parties having a single insurance policy with the same insurance company to cover all risks is now widely adopted, thereby avoiding the possibility that the different insurance companies will egg the parties on to litigation in order to shift the risk on to each other (one might say in passing that the time must surely soon come when the doctrine of subrogation is re-examined to see whether in practice it produces desirable or undesirable results in terms of litigation). ${ }^{52}$

\section{Certainty in commercial contracts}

Outside the field of exemption clauses there have been a number of indications of a swing back to valuing the virtues of certainty, particularly in commercial contracts. I have in mind such decisions as Bunge v. Trada $x^{53}$ indicating that in appropriate circumstances the court will decide that a contractual term is a condition, even though the parties have not formally so classified it, because of its importance. Perhaps even more significant is the line of cases from the Laconia ${ }^{54}$ to the Chikuma ${ }^{55}$ in which the House of Lords has rebuffed repeated attempts by the Court of Appeal to permit relief to a party who pays a little late where the

52. Hasson, 5 Oxford 7.L.S.416.

53. [1981] 2 All E.R.513.

54. [1977] A.C.850.

55. [1981] 1 All E.R.652. 
contract entitles the other party to terminate for failure in prompt payment. The refusal to spread the doctrine of relief against forfeiture into the area of commercial contracts in such cases as Sport International Bussum v. Inter-Footwear ${ }^{56}$ is part of the same trend. These developments have been accompanied by a more elaborate and sophisticated analysis of the effect of breach of contract to which both Lord Wilberforce ${ }^{57}$ and Lord Diplock ${ }^{58}$ made major contributions. Difficulties may lie ahead however in deciding how far the decision of the majority of the House of Lords in Hyundai v. Papadopoulos ${ }^{59}$ that termination leaves unaffected pre-termination obligations to pay money is to be carried.

\section{Consumer protection}

I am inclined to think in general that change in the law of contract for the purposes of consumer protection has now reached something near the limits of useful development and that the steps which at least in the short term are required to carry things forward are to be found either in the expansion of the Criminal Law or in the provision of much cheaper, quicker methods of dispute settlement. It is noticeable if one looks at the cases how few consumer durables give rise to litigation outside the motor industry, and how many of the cases even within the motor industry were brought by the finance companies who continued to insist on payment in full for shoddy cars rather than by consumers asking for their money back. It is $I$ think clear, if one looks at the cases, that in nearly all of them the consumer would in practice have been perfectly content to abandon the vehicle and the money he had already paid, in order to get rid of the transaction. The average consumer finds it difficult to complain and finds the thought of litigation intolerable.

\section{Inequality of bargaining power}

One of the most stimulating and controversial initiatives by Lord Denning in the field of Contract Law was his suggestion in Lloyds Bank v. Bundy ${ }^{60}$ that there was a general doctrine which could be drawn together from a number of specific examples that a court would interfere with an agreement where one party had taken unfair advantage of a superiority in his bargaining position. On the whole this was received with a somewhat chilly response from English commentators on the grounds that inequality of bargaining power is a vague notion, difficult to describe, analyse or apply. ${ }^{61}$ The notion has also been received with less than rapturous enthusiasm by many judges, particularly by the House of Lords, in National Westminster Bank v. Morgan. ${ }^{62}$ It is notable, however, that in all the cases

56. [1984] 2 All E.R.321.

57. See, e.g., fohnson v. Agnew [1980] A.C.367.

58. See, e.g., Photo Production v. Securicor [1980] A.C.827.

59. [1980] 2 All E.R.29.

60. [1975] Q.B.326.

61. See, e.g., Treitel, The Law of Contract (6th edition 1983), pp.317-318.

62. [1985] A.C.686. 
where courts have been asked to apply the doctrine and have refused to do so, the judges have been careful first of all to make it clear that the actual contract that they were considering fell comfortably within the area of permissible negotiating tactics. So in Burmah Oil v. Bank of England, ${ }^{63}$ in Alec Lobb v. Total Oit ${ }^{64}$ and in Morgan itself, ${ }^{65}$ the primary reason for the decision was that the contract was in fact fair. Of course, to test the Denning thesis, we need to find a case in which a judge will say that the contract is clearly unfair; that the parties were clearly in an unequal bargaining position, but that the court can do nothing about it. I think it may be some time before this case emerges! If this is correct, then we cannot yet exclude the possibility that in a suitable case some court will feel that the existing pigeon holes do not quite fit the case but that the case requires judicial intervention. In such a case, an appeal may be made again to the spirit of Bundy. It is noteworthy in this respect that Lord Denning's judgment has received much more enthusiastic reception in Canada. Canadian contract law appears to be much more open to the reception of this kind of broad-brush approach. ${ }^{66}$

\section{Contract theory}

Some of the questions discussed above implicitly raise questions of what the law of contract is about; what its objectives are and should be, and what is the underlying basis of contractual obligation. These questions having been neglected for thirty years are very much to the fore again. Professor Patrick Atiyah has argued in his usual persuasive fashion that the underlying rationale of the law of contract is or should be reliance rather than the satisfaction of expectations. ${ }^{67}$ So far I must confess to finding the evidence that this is so less than wholly convincing, but the debate is clearly a fruitful one. Questions about reliance are particularly important in relation to the final resolution of doubts about promissory estoppel. It is an illustration of both the strength and the weakness of evolution through the cases that High Trees ${ }^{68}$ should have appeared as if from nowhere in 1947 but that we should still be unsure forty years later where its precise limits lie. Similarly, contract lawyers have learned much and will learn more from the application of economic analysis which has been particularly illuminating in the context of contractual remedies. Indeed, the whole question of remedies, for so long a topic shuffled off to the end of the course and the back of the book, has moved very much to centre stage; an important example is the new debate as to whether specific performance should be granted on a significantly wider basis than it has

63. (1981) Unreported.

64. [1985] 1 All E.R.303.

65. The different way in which the same facts are presented by the Court of Appeal [1983] 3 All

E.R.85 and the House of Lords is striking in this respect.

66. See, e.g., Morrison v. Coast Finance (1965) 55 D.L.R. (2d) 710; Black v. Wilcox (1976) 70 D.L.R.

(3d) 192; Waddams in Lord Denning: The Fudge and the Laws Ch.10.

67. See e.g., Atiyah, The Rise and Fall of Freedom of Contract, pp.184-189; Promises, Morals and the Law, pp.36-42; 102 L.Q.R. 363.

68. [1947] K.B.130. 
been in the past. As I was writing an earlier draft of these words I received in the post a report of the decision in Posner v. Scott-Lewis ${ }^{69}$ (a happily named case!?) where specific performance was granted of an agreement by a landlord to provide a residential porter in a block of flats. This was a classic example of a stipulation which could not be adequately compensated by a payment of damages but where authority might well have persuaded judges twenty or thirty years ago not to accede to an application for specific performance.

69. [1986] 3 All E.R.513. 